\title{
X’e Băglı Resesif Geçiş Gösteren Herediter Spastik Paraparezili Bir Türk Ailesi
}

\author{
Dilcan Kotan, Saadet Sayan, Aslı Aksoy Gündoğdu \\ Sakarya Üniversitesi Tıp Fakültesi Nöroloji Anabilim Dalı, Sakarya,Türkiye
}

Kotan D, Sayan S, Gündoğdu Aksoy A. 201X. X’e Bağlı Resesif Geçiş Gösteren Herediter Spastik Paraparezili Bir Türk Ailesi, Osmangazi Tip Dergis $\dot{I}$, 40(3):122-124 Doi: 10.20515/otd.295831

\section{Editöre Mektup,}

Erişkin yaşa dek tanı almamış, aynı aileden altı erkek bireyin etkilendiği herediter spastik paraparezi (HSP) olgularını tanımladık. Bu yazıda, ender görülen bu hastalığın bulguları ve genetik teşhisinin ülkemizde zorlukları hakkındaki görüşlerimizi literatür eşliğinde sunuyoruz.

HSP, alt ekstremite kaslarında güçsüzlük ve spastisite ile semptom veren, progresif seyirli nadir bir nörojeneratif hastalıktır (1). Klinik ve genetik olarak heterojenite gösterir. Fenotipe göre "saf" HSP ve "komplike" HSP olarak iki geniş gruba ayrılır. Genetik olarak otozomal dominant, otozomal resesif, mitokondrial veya $X^{\prime}$ e bağl1 resesif gibi çeşitli kalıtsal geçiş özellikleri tespit edilebilir (2). Genellikle otozomal dominant geçişli olmasına rağmen, akraba evliliklerinin sıklıkla görüldüğü toplumlarda resesif tip de sıklıkla ortaya çıkmaktadır.

Hastalığın klinik tablosu, kortiko-spinal traktusun uzunluğa bağımlı dejenerasyonuna bağlıdır. Öncelikle alt ekstremiteleri innerve eden en uzun lifler etkilenmiştir. Karakteristik olarak, alt ekstremite kas güçsüzlügü, spastisite ve ekstansör plantar ortaya çıkmaktadır. Bunun yanında birçok olguda, ataksi, ağır amiyotrofi, optik atrofi, pigmenter retinopati, mental retardasyon, ekstrapiramidal bulgular, demans, sağırlık, iktiyozis, periferal nöropati ve epilepsi gibi bulgular eşlik edebilmekte ve bu grup olgular komplike HSP olarak adlandırılmaktadır (3).

$\mathrm{Bu}$ yazıda, ikinci dekaddan sonra sağ bacakta incelme ve ağrı ile semptomatik olan, ilerleyici yürüme güçlüğüne sahip 41 yaşındaki erkek hastamız ailesindeki bireylerle birlikte incelendi. Olgunun detayl nörolojik ve fizik muayene bulguları, laboratuvar testleri, görüntüleme özellikleri, elektrofizyolojik ve genetik incelemeler ile birlikte değerlendirildi. İndeks olgumuz ve ailesindeki etkilenmiş altı erkekte mitokondriyal geçiş düşündürdü (Şekil 1). 


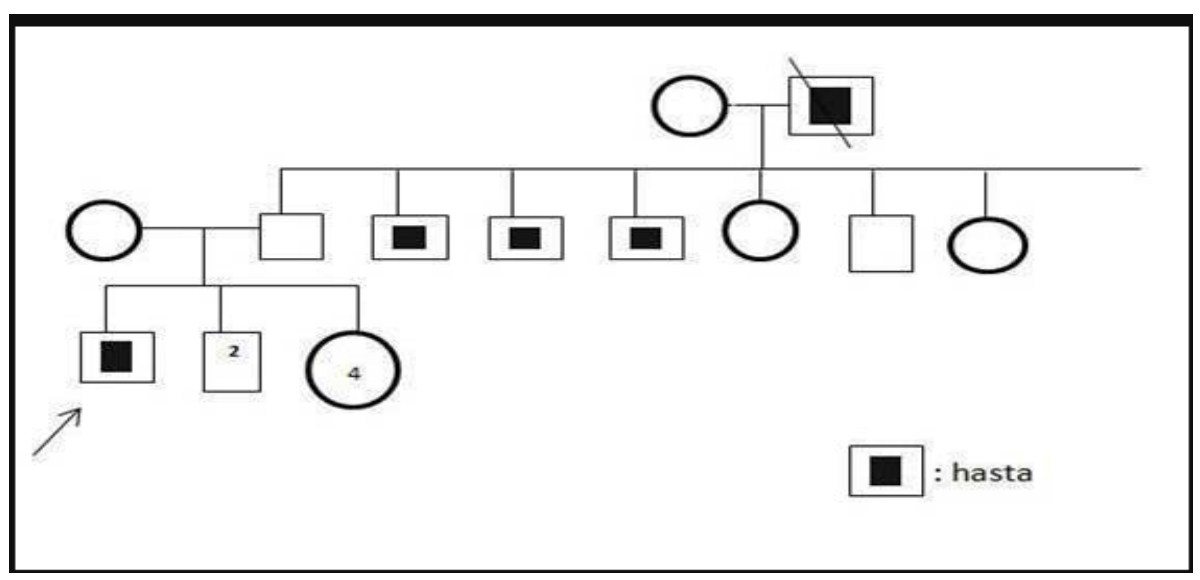

Şekil 1. HSP Ailesinde Mitokondriyal Geçişi Gösteren Pedigri Şeması

İndeks olgumuz, ikinci dekaddan sonra farkettiği sağ bacakta incelme, ve son altı ayda ortaya çıkan bacaklarda ağrı ve ilerleyici yürüme güçlüğü ile kliniğimize başvurdu. Öz geçmişinde özellik yoktu. Anne ve babası aynı köyden idi, ancak aralarında akrabalık yoktu. Ailesinde babada, üç amcada ve dedede yürüme güçlüğü olduğu öğrenildi. Nörolojik muayenesinde; yüksek damak, paraparezi (4/5 motor kuvvet), bilateral alt ekstremitelerde belirgin atrofi, , gastroknemius kaslarında psödohipertrofi dikkat çekmekteydi. Bilateral pes-cavus, çekiç parmak ve spastisite, spastik yürüyüş, dört ekstremitede artmış derin tendon refleksleri, bilateral ekstansör taban cildi refleksi mevcuttu. Kas gücü kaybı veya duyusal bulguları yoktu. Kranyal ve spinal görüntülemesi normal, serum kreatinin kinaz (CK) düzeyi 63 (N: 20-200 mU/L) idi. Akrabaları arasında 96 yaşındaki anneanne, 72 ve 68 yaşındaki halaları ve annesinin nörolojik muayenesi normal idi. 54 yaşındaki babanın yüksek damak, sol alt ekstremitesinde hafif spastisite ve derin tendon reflekslerinin canlı olması dışında nörolojik muayenesi doğal idi. 7-8 yıldır yürüme güçlüğü yaşayan 61 yaşındaki amcanın nörolojik muayenesinde, alt ekstremitede belirgin spastisite, dört ekstremitede canlı derin tendon refleksleri ve bilateral ekstansör taban cildi refleksi mevcut olup, yürüyüş spastik idi. 4-5 yıldır yürüme güçlügü yaşayan 60 yaşındaki amcanın nörolojik muayenesinde; torakal kifoskolyoz, yüksek damak, alt ekstremitede hakim spastisite mevcuttu ve derin tendon refleksi dört ekstremitede canlı, taban cildi bilateral lakayt idi. 3-4 yıldır yürüme güçlüğü yaşayan 51 yaşındaki amcanın nörolojik muayenesinde; yüksek damak, hafif spastik yürüyüş dişında özellik yoktu. Hastalık öyküsü olan diğer amcaya ulaşılamadı.

HSP tanıs1; normal nörolojik gelişimi takip eden, alt ekstremitede hakim spastisite, kas güçsüzlüğü, hiperrefleksi ve ekstansör plantar yanıtın varlığı, olası edinsel nedenlerin dışlanması ve/veya aile öyküsünün varlığı ile konulmaktadır. İncelediğimiz altı olguda HSP ile uyumlu nörolojik muayene bulguları mevcuttu.

HSP genleri tarafindan kodlanan proteinler, hücre içi membran ve protein akışında, aksonal transportta, hücre iskeleti düzenlenmesinde ve mitokondriyal işlevlerde rol alır. Spastik paraparezi 7 (SPG7) ve SPG13 mitokondrial hastalıklar grubundandir (4). Pedigri değerlendirildiğinde hastalığın mitokondriyal kalıtıldığ 1 düşünülen ve genetik incelemeye yönlendirilen olgularımızın ekzom analizi sürmektedir.

HSP'de klinik bulgular genellikle 3-5. dekadda başlar. Bulgular saf HSP ile uyumlu olabileceği gibi ek nörolojik veya sistemik bulgular da görülebilir. Siklıkla İtalyan ve Fransız ailelerde tanımlanmıştır. Piramidal bulgular yan1 s1ra, beyin sap1 bulgular1, derin duyu bozukluğu, alt ekstremitelerde belirgin güçsüzlük, pes kavus, skolyoz gibi iskelet 
deformiteleri de görülebilir $(4,5)$. Serum CK düzeyleri artabilir, kranyal manyetik rezonans görüntülemede (MRG) serebral veya serebellar atrofi görülebilir. Bizim indeks olgumuzda ve ailesindeki bireylerde CK düzeyi ve nörogörüntüleme bulguları normal idi.

HSP ayırıc1 tanisinda spinal kord hasarlanmaları, infeksiyöz, iskemik, metabolik, inflamatuvar myelopatiler göz önünde bulundurulmalıdır (3). Biz de indeks olgumuz ve diğer incelediğimiz aile bireylerinde, öykü ve klinik değerlendirme, vitamin B12, folik asit, ferritin düzeyleri gibi laboratuvar testleri, kranyal ve servikal MRG ile olası edinsel nedenleri dışladık.

Klinik yansımalar ve genetik özellikler birlikte incelendiğinde, bölgeler arasında dağılım farklılığı olmakla birlikte, yalnızca spastisite ile seyreden vakalar çoğunlukla OD geçiş gösterirken, komplike vakalar genellikle OR geçiş göstermektedir (6). Bizim altı HSP olgumuz saf HSP formunda idi. Her kuşakta hastalık ortaya çıkmıştı ancak hiç etkilenmiş kadın olmaması nedeniyle mitokondriyal geçiş düşünüldü ve genetik incelemeye yönlendirildi.

Moleküler biyoloji ve nörogenetik alanında son on yıldaki ilerlemeler ile günümüzde HSP ile ilgili yüze yakın genetik lokus ve gen tanımlanmıştır ve çalışmalar devam etmektedir (6). $\mathrm{Bu}$ kadar geniş genetik yelpazeye sahip olması hastalığın tanı konma sürecini uzatmakta ve zaman zaman eldeki imkanlar yetersiz kalmaktadır.

\section{KAYNAKLAR}

1. Fink JK. Advances in hereditary spastic paraplegia. Curr Neurol 1997: 10: 313-318.

2. Finsterer J, Loscher W, Quasthoff S, et al. Hereditary spastic paraplegias with autosomal dominant, recessive, $\mathrm{X}$-linked or maternal trait of inheritance. J Neurol Sci 2012;318:1-18.

3. Fink JK. Hereditary spastic paraplegia: clinico-pathologic features and emerging molecular mechanisms. Acta Neuropathol 2013;126:307-28.

4. Casari G, De Fusco M, Ciarmatori S, et al. Spastic paraplegia and OXPHOS impairment caused by mutations in paraplegin, a nuclear-encoded mitochondrial metalloprotease. Cell 1998;93: 973.

5. Fontaine B, Davoine C.-S, Durr A, et al. A new locus for autosomal dominant pure spastic paraplegia, on chromosome 2q24q34. Am. J. Hum. Genet. 2000; 66:702.

6. S. Klebe, G. Stevanin, C. Depienne. Clinical and genetic heterogeneity in hereditary spastic paraplegias: from SPG1 to SPG72 and still counting. Rev Neurologique 2015;171(6):505-30. 